\title{
Determination of heavy metals in the bioindicator plant Tradescantia pallida var. Purpurea
}

\author{
Thiago P B De Luccia \\ Correspondence: tpbl78@yahoo.com.br \\ Department of Family and Community Medicine, University of Sao Paulo - Brazil. \\ Av. Dr. Arnaldo, 455 - Cerqueira César - CEP: 01246-000 - São Paulo - SP - Brazil.
}

\begin{abstract}
Background: There is an interest in developing cheaper and effective methodologies for air pollution monitoring. Thus, biological materials such as plants and animals accumulators of metals have been studied for use in biomonitoring of air pollution. The plant chosen for biomonitoring in the present study was the Tradescantia pallida var. Purpurea

(T. pallida). The harmful effects of environmental pollution have been already evidenced by micronucleus assays using the species T. pallida. Three Brazilian studies identified accumulation in leaves of T. pallida of important elements for air pollution biomonitoring using neutron activation analysis. Here, a new methodology using atomic emission spectroscopy with inductively coupled plasma was evaluated.

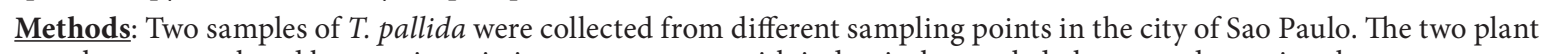
samples were analyzed by atomic emission spectroscopy with inductively coupled plasma to determine the concentrations of the heavy metals cadmium, lead, lithium, nickel, zinc, cobalt and manganese in the leaves of the species T. pallida.

Results: Making a comparison between concentrations of elements found in the two samples, Mn and $\mathrm{Zn}$ appeared in greater quantity in sample 1 (the collection point was a sidewalk next to an avenue with intense traffic of cars metropolitan region Sao Paulo) than in sample 2 (residential neighborhood - metropolitan region Sao Paulo). Most of the concentrations of the elements were similar and appeared above the detection level of the device (ICP-AES) Spectro Ciros CCD.

Conclusions: All metals were detected in the dry biomass of the plants which brings more elements to the study of this species as a bioindicator of environmental pollution. Here we can not say if the metals were absorbed by the roots or by aerial parts, but establish the levels of these metals in such kind of plant with this methodology can be useful for further studies.
\end{abstract}

Keywords: Tradescantia pallida, heavy metals, environmental pollution

\section{Background}

There is an interest in developing cheaper and effective methodologies for air pollution monitoring [1]. Thus, biological materials such as plants and animals accumulators of metals have been studied for use in biomonitoring of air pollution [1]. The plant chosen for biomonitoring in the present study was the Tradescantia pallida var. Purpurea, a species of ornamental Commelinaceae family. This plant was chosen because of its wide distribution in the city of Sao Paulo and it is a plant that propagates easily, even in regions of high pollution level, as the center of Sao Paulo. The harmful effects of environmental pollution has been evidenced by micronucleus assays using the species T. pallida. It has been found that the more micronucleus were formed, when more polluted is the air $[2,3]$. This species also has been used to assess air quality in different areas and in different periods [4], and also to detect variations in the concentrations of atmospheric gases by micronucleus analysis [5]. Few studies quantified the concentrations of metals in this specie and these studies suggest that some metals such as manganese and zinc occur in highest concentrations in plants exposed to polluted environments such as central regions of large cities. The studies that evaluated the concentrations of metals in this species until then, used neutron activation analysis, and here, we use atomic emission spectroscopy with inductively coupled plasma as an alternative to this kind of analysis. The aim of this study was to determine the concentrations of heavy metals (cadmium, lead, lithium, nickel, zinc, cobalt and manganese) in the leaves of the species T. pallida. These heavy metals were chosen because the importance of them to human health. Such metals can be found in greater quantity in the soil and in the air depending on environmental factors. The pollution generated by motor vehicles and factories as well as poor disposal of solid 
Table 1.The two columns present the dosages (ppm) of heavy metals in two samples of T. pallida.

\begin{tabular}{ccc}
\hline Metals & $\begin{array}{c}\text { Biomassa } \\
\text { (sample 1) }\end{array}$ & $\begin{array}{c}\text { Biomassa } \\
\text { (sample 2) }\end{array}$ \\
\hline $\mathrm{Cd}$ & 0,008 & 0,008 \\
$\mathrm{Co}$ & $<0,02$ & $<0,02$ \\
$\mathrm{Li}$ & $<0,002$ & $<0,002$ \\
$\mathrm{Mn}$ & 205,06 & 141,71 \\
$\mathrm{Ni}$ & 0,01 & 0,01 \\
$\mathrm{~Pb}$ & 0,01 & 0,01 \\
$\mathrm{Zn}$ & 63,63 & 62,04 \\
\hline
\end{tabular}

waste are causes of increased level of such metals.

\section{Methods}

Two samples of T. pallida were collected from different sampling points in the city of Sao Paulo in the month of March 2012. The first collection point was a sidewalk next to an avenue with intense car traffic (sample 1) (Latitude: -23.539354 Longitude: -46.728159). (15 different plants collected). The second collection point was a sidewalk in a residential neighborhood (Latitude: -23.5612609 Longitude: -46.7469433) (sample 2) (15 plants collected). For analysis of these leaves they were washed with deionized water to remove possible dust particles deposited and drying was done in a stove with forced air circulation, an average temperature of 40 oC for approximately 2 days. The samples of leaves were grinded and mixed. These samples in powder form were stored in plastic pots which were stored in a desiccator $(10 \mathrm{~g}$ of biomass for each group of plants). The methodology used in the digestion of plant samples was based on the method 3052 - Microwave Assisted Acid Digestion of Siliceous and Organically Based Matrices (U.S. EPA 1996).

The two plant samples were analyzed by atomic emission spectroscopy with inductively coupled plasma (ICP-AES) Spectro Ciros CCD in Central Analytical Laboratory at the Institute of Chemistry of the University of São Paulo. The atomic emission spectrometry is a technique used for quantitative determination of metals in higher concentration levels (percentage) and traces ( $\mathrm{mg} / \mathrm{L}$ to $\mu \mathrm{g} / \mathrm{L}$ ) in a wide variety of samples, such as geological and environmental samples, water, steels and alloys, plants and food. This technique is a quick method for a high sensitivity for the determination of metals, which can detect very low concentrations. The fundamental principle of atomic emission spectrometry is the ionization of the elements to be analyzed by Inductively coupled plasma of argon sustained by a magnetic field that is generated by a radio frequency coil. Plasma samples pass through a nebuliser system and are transported in aerosol form. The samples undergo a series of physical-chemical processes: desolvation, vaporization and atomization.

\section{Results}

Making a comparison between concentrations of elements found in the two samples, $\mathrm{Mn}$ and $\mathrm{Zn}$ appeared in greater quantity in sample 1. Most of the elements dosages of biomass was similar and appeared above the level of detection of the device (ICP-AES) Spectro Ciros CCD. in Table 1 we see the results of measurements of metals in the two samples. With only two plant samples, that generated two homogenized biomass of the fifteen plants collected in each different region, it was not possible to analyze whether there is a statistical difference between the two samples. In our study the average of two samples of manganese was 173,3 ppm (standard deviation of $44,8 \mathrm{ppm}$ ). The average of two samples of zinc was 62,8 (standard deviation of 1,10ppm).

\section{Discussion}

In a study that examined the uptake of metals by plants (sunflowers, oats and grass-Bahiagrass), grown in soils with different levels of heavy metals ( $\mathrm{Cd}$ element varying from 1.9 to $22.1 \mathrm{mg} \mathrm{kg}^{-1}$ ), the concentrations of $\mathrm{Cd}$ were 1.32 till $43.50 \mathrm{mg} \mathrm{kg}^{-1}$ (sunflower), 0.00 till $67.92 \mathrm{mg} \mathrm{kg}^{-1}$ (oat) and 0.40 till $37.25 \mathrm{mg} \mathrm{kg}^{-1}$ (gram-Bahiagrass). The highest levels of $\mathrm{Cd}$ in the aerial parts of these plants occurred when grown in soil with $22.1 \mathrm{mg} \mathrm{kg}^{-1}$. The uptake by the roots and translocation of the element to the aerial parts of plants occurred according to the quantity of the element in the soil [6]. In our dosages found in both groups of plants were $0.008 \mathrm{mg} \mathrm{kg}^{-1}$ (converted value).

Cobalt is an element found in soils, rocks, water, plants and animals in trace quantities. In analysis by neutron activation in leaves of T. pallida, there was variation in the dosages of the element in the three regions to which the plants were exposed: Jabaquara (metropolitan region of Sao Paulo - region of industries) $90 \mathrm{ng} \mathrm{g}^{-1}(\mathrm{SD} \pm 2)$, University of Sao Paulo (metropolitan region Sao Paulo - wooded campus) $83 \mathrm{ng} \mathrm{g}^{-1}(\mathrm{SD} \pm 1$ ), North Caucaia (region considered slightly polluted - control) $48 \mathrm{ng} \mathrm{g}^{-1}(\mathrm{SD} \pm 3$ ) [7]. In a study in Santo André city (Brazil), using neutron activation analysis, it was identified in T. pallida an evident accumulation in leaves of important elements for air pollution biomonitoring, such as: $\mathrm{Ba}, \mathrm{Ce}, \mathrm{Co}, \mathrm{Cr}, \mathrm{Cs}, \mathrm{La}, \mathrm{Rb}, \mathrm{Sb}, \mathrm{Sc}$ and $\mathrm{Zn}$. In this study, no relation between the concentrations of metals in the leaves inserted in the inflorescences and the frequency of micronuclei was observed. However, the metal concentrations could discriminate specific sites, contributing to the mapping of polluted sources in each region studied [8]. Our dosages in both groups of plants were less than $0.02 \mathrm{mg} \mathrm{kg}^{-1}$ (converted value).

Plants absorb several elements that appear not to play a role in their metabolism, namely arsenic (As), chromium $(\mathrm{Cr})$, cobalt $(\mathrm{Co})$, fluorine $(\mathrm{F})$, lodine $(\mathrm{I})$, lead $(\mathrm{Pb})$, lithium $(\mathrm{Li})$ and selenium (Se). The study of Magalhães [9] showed that the absorption of lithium per radish, lettuce and watercress increases due to the amount of lithium present in the experimental solutions in which the plants are placed. 
Thiago P B De Luccia Journal of Environmental Engineering \& Ecological Science 2012,

Lithium dosed in watercress increased from 37 till 1216 ppm, when the experimental solution of lithium grew from 0.1 till $2.0 \mathrm{mM}$. In radish, lithium increased from 17 till 1008 ppm and in lettuce 11 till 508 ppm [9]. In our plant samples Li values were less than $0.002 \mathrm{mg} \mathrm{kg}^{-1}$ (converted value).

Manganese acts on the basal metabolism of plants (photosynthesis and transfer of phosphate), stabilizing the structure of the chloroplast and nucleic acid synthesis. In a study by short irradiation technique of neutron activation analysis in samples of leaves of T. pallida $\mathrm{Mn}$ was dosed 132-314 (in $\mu \mathrm{g} \mathrm{g}^{-1}$ ) for plants grown in regions with different levels of pollution [10]. In this study the region with the highest metered quantity of manganese in samples of leaves of T. pallida was an area with a lot of traffic from vehicles and factories (Jabaquara - metropolitan region of Sao Paulo). Using the artifice of incorporating the dosages of manganese from this study (analysis by neutron activation) with our results, grouping seven dosages of manganese from different regions of the State of Sao Paulo we get an average of $166.2 \mathrm{mg} \mathrm{kg}^{-1}$ (standard deviation of $83,7 \mathrm{mg} \mathrm{kg}^{-1}$ ). The dosage of the region considered slightly polluted of the study by neutron activation was

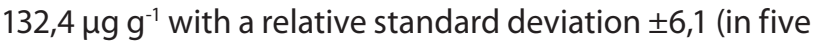
determinations). In our sample 2 the dosage of $\mathrm{Mn}$ was $141,71 \mathrm{ppm}$ (residential neighborhood). The dosage of the region considered polluted of Sao Paulo by neutron activation was 314,0 (SD $\pm 14,6$ in six determinations). In our sample 1 (from an avenue with intense car traffic) the dosage was $205,06 \mathrm{ppm}$. There is an apprehension that industrial emissions of $\mathrm{Mn}$ and the use of $\mathrm{Mn}$-containing compounds as fuel additives may increase the population risk of Parkinson's disease-like disorders. A canadian study sugested that exposure to ambient $\mathrm{Mn}$ advances the age of diagnosis of Parkinson's disease, coherent with the hypothesis that exposure to Mn adds to the usual loss of neurons attributable to the aging process [11].

In the study by Andrade [6], plants sunflowers, oats and grass-Bahiagrass, grown in soils with different levels of nickel (16.5 till $\left.38.4 \mathrm{mg} \mathrm{kg}^{-1}\right)$ the quantities of the element found in the aerial parts of plants were: 0.11 till $10.74 \mathrm{mg} \mathrm{kg}$ ${ }^{-1}$ (Sunflower), 0.73 till $52.70 \mathrm{mg} \mathrm{kg}^{-1}$ (black oats) and 2.83 till $11.88 \mathrm{mg} \mathrm{kg}^{-1}$ (Grass-Bahiagrass). The highest levels of $\mathrm{Ni}$ in aerial parts of these plants occurred when grown in soil with $11.88 \mathrm{mg} \mathrm{kg}^{-1}$. Our plant samples values were 0.01 ppm (Ni). Nickel, according with Dixon [12], is considered a functional plant nutrient and the appropriate level of the element in the tissues is $0.05 \mathrm{mg} \mathrm{kg}^{-1}$ by the author.

In the study with plants (sunflowers, oats and grassBahiagrass) grown in soils with different levels of $\mathrm{Pb}$ (234.8 till $9678.2 \mathrm{mg} \mathrm{kg}^{-1}$ ) the quantities of the element found in the aerial parts of plants were: 4.94 till $213.93 \mathrm{mg} \mathrm{kg}^{-1}$ (Sunflower), 1.19 till $130.25 \mathrm{mg} \mathrm{kg}^{-1}$ (black oats) and from 1.32 till $171.10 \mathrm{mg} \mathrm{kg}^{-1}$ (Grass-Bahiagrass ). The highest levels of $\mathrm{Pb}$ in the aerial parts of these plants occurred when grown in soil with $9678.2 \mathrm{mg} \mathrm{kg}^{-1}$ [6]. Our dosages of the two groups of plants were $0.01 \mathrm{ppm}$.

With respect to zinc in analysis by neutron activation, a variation in the dosages of the element in the three regions to which the plants were exposed was noted: Jabaquara (region of industries) $193 \mathrm{mg} \mathrm{g}^{-1}(\mathrm{SD} \pm 6)$, University of Sao Paulo (wooded campus in Sao Paulo city) $63 \mathrm{mg} \mathrm{g}^{-1}$ $(\mathrm{SD} \pm 4)$, North Caucaia (region considered slightly polluted) 56 $\mathrm{mg} \mathrm{g}^{-1}(\mathrm{SD} \pm 4)$ [7]. In our study, in the sample 1 we got $(63,63$ $\mathrm{ppm})$ and in the sample $2(62,04 \mathrm{ppm})$. $\mathrm{Zn}$ average of two samples was 62,8 (SD $\pm 1,10 \mathrm{ppm})$. Airborne concentrations of zinc in suspended particulate matter is higher in industrial areas and brass industries are mainly responsible for this. In a study conducted in India observed maximum concentrations of $\mathrm{Zn}$ at industrial site and minimum at residential site [13]. The concentration of $\mathrm{Zn}$ was also higher in urban than rural regions in another study [14]. A study conducted in Sao Paulo employing Tillandsia usneoides $\mathrm{L}$. as biomonitor found $\mathrm{Zn}$ and $\mathrm{Co}$ highest contents related to industrial zones and associated to the presence of anthropogenic emission sources [15]. Zn was evidently accumulated in leaves of T.pallida from the industrial areas of Santo Andre city, being considered indicator of emissions from the petrochemical pole in another study [8]. Among the particulate matter with aerodynamic diameter less than $2.5 \mu \mathrm{m}$ (PM2.5) constituents, $\mathrm{Zn}$ showed the most significant associations with the increase in tumor necrosis factor alpha (TNF-a), a circulatory biomarker associated with activation of systemic inflammation and hypercoagulability and increased plasma homocysteine, mechanisms through which air pollution may influence the cardiovascular system [16].

\section{Conclusions}

All metals were detected in the dry biomass of T. pallida plants which brings more elements to the study of this species as a bioindicator of environmental pollution. Here we cannot say if the metals were absorbed by the roots or by aerial parts, but establish the levels of these metals in such kind of plant with this methodology can be useful for further studies. Analyze other elements of interest from the point of environmental pollution as well as the analysis of this species grown in soils with the same composition and in places exposed to different levels of air pollution could bring more elements to the study of T. pallida as a potential bioindicator plant. We can assume that T. pallida absorbs more zinc and manganese from the environment depending on the level of air pollution in the region, however, this remains to be demonstrated with specific methodology.

\section{Competing interests}

The author declare that he has no competing interests.

\section{Author contribution}

Thiago Paes de Barros de Luccia wrote and 
produced the entire article.

\section{Publication history}

Received: 07-Dec-2012 Revised: 19-Dec-2012

Accepted: 25-Dec-2012 Published: 31-Dec-2012
16. Wu S, Deng F, Wei H, Huang J, Wang H, Shima M, Wang X, Qin Y, Zheng $C, H a o Y$ and Guo $X$ : Chemical constituents of ambient particulate air pollution and biomarkers of inflammation, coagulation and homocysteine in healthy adults: A prospective panel study. Part Fibre Toxicol 2012, 9:49. | Article | PubMed

\section{References}

1. Fuga M, Saiki MA, Vasconcellos NK and Honda OS: Analysis of epiphytic lichen species for use in biomonitoring air pollutants. Rev. Bras. Pesq. Des. 2002, 4:1183-1187.

2. Steinkellner H, Mun-Sik K, Helma C, Ecker S, Ma TH, Horak O, Kundi $\mathrm{M}$ and Knasmuller $\mathrm{S}$ : Genotoxic effects of heavy metals: comparative investigation with plant bioassays. Environ $\mathrm{Mol}$ Mutagen 1998, 31:183-91. | Article | PubMed

3. Batalha JR, Guimaraes ET, Lobo DJ, Lichtenfels AJ, Deur T, Carvalho HA, Alves ES, Domingos M, Rodrigues GS and Saldiva PH: Exploring the clastogenic effects of air pollutants in Sao Paulo (Brazil) using the Tradescantia micronuclei assay. Mutat Res 1999, 426:229-32. | Article I PubMed

4. Misik M, Micieta K, Solenska M, Misikova K, Pisarcikova $\mathrm{H}$ and Knasmuller S: In situ biomonitoring of the genotoxic effects of mixed industrial emissions using the Tradescantia micronucleus and pollen abortion tests with wild life plants: demonstration of the efficacy of emission controls in an eastern European city. Environ Pollut 2007, 145:459-66. | Article | PubMed

5. Xu Z, Ma T: Clastogenicity of formaldehyde fumes and X-rays evaluated by the Tradescantia - micronucleous assay. Environ. Exp. Bot 1998, 39:169-175. | Article

6. Andrade MG, Melo VF, Gabardo J, Souza LCP, Reissmann CB: Heavy metals in soils of mining and metallurgy of lead - phytoextraction. R. Bras. Ci. Solo 2009, 33:1879-1888. | Article

7. Tavaraya AK, Saiki M, Sumita MN and Saldiva PHN: Analysis neutron activation plant tradescantia pallida for use in monitoring of air pollutants. | PDF

8. Savoia, Eriane Justo Luiz: Potencial de Tradescantia pallida cv. Purpurea para biomonitoramento da poluição aérea de Santo André - São Paulo, por meio do bioensaio Trad - MCN e do acúmulo foliar de elementos tóxicos [dissertation]. São Paulo: University of São Paulo, Faculdade de Medicina; 2007 [Accessed 2012-12-26]. | Website

9. Magalhães JR, Wilcox GE, Rocha ANF,Silva FLIM: Research on lithium-phytological metabolism. Pesq. agropec. bras. Brasília 1990, 25:1781-1787. | PDF

10. Determinação de $\mathrm{Cl}, \mathrm{Mg}, \mathrm{Mn} \mathrm{E} \mathrm{Na}$ Em amostras da planta Tradescantia pallida. Determination of $\mathrm{Cl}, \mathrm{Mg}, \mathrm{Mn}$ and $\mathrm{Na}$ in samples of plant Tradescantia pallida. I PDF

11. Finkelstein $M M$ and Jerrett $M: A$ study of the relationships between Parkinson's disease and markers of traffic-derived and environmental manganese air pollution in two Canadian cities. Environ Res 2007, 104:420-32. | Article

12. Dixon NE, Gazzola TC, blakeley RL and Zermer B: Letter: Jack bean urease (EC 3.5.1.5). A metalloenzyme. A simple biological role for nickel? J Am Chem Soc 1975, 97:4131-3. | Article | PubMed

13. Tripathi A, Dwivedi AK and Mahima: Airborne $\mathrm{Cu}$ and $\mathrm{Zn}$ at some urban sites in Pital Nagri (Moradabad), India. J Environ Sci Eng 2010, 52:53-6. | Article | PubMed

14. Shridhar V, Khillare PS, Agarwal T and Ray S: Metallic species in ambient particulate matter at rural and urban location of Delhi. $J$ Hazard Mater 2010, 175:600-7. | Article | PubMed

15. Figueiredo AM, Nogueira CA, Saiki M, Milian FM and Domingos M: Assessment of atmospheric metallic pollution in the metropolitan region of Sao Paulo, Brazil, employing Tillandsia usneoides $L$. as biomonitor. Environ Pollut 2007, 145:279-92. | Article | PubMed

\section{Citation:}

De Luccia TPB: Determination of heavy metals in the bioindicator plant Tradescantia pallida var. Purpurea. journal of Environmental Engineering and Ecological Science 2012, 1:4.

http://dx.doi.org/10.7243/2050-1323-1-4 